\title{
Case Study and Direction of Bicycle-Sharing Systems in Japanese Cities
}

\author{
Minoru Kumano \\ Faculty of Regional Innovation, University of Miyazaki, Japan \\ E-mail: kumano@cc.miyazaki-u.ac.jp \\ Toru Hiraoka \\ Department of Information Systems, University of Nagasaki, Japan \\ E-mail: hiraoka@sun.ac.jp
}

\begin{abstract}
Bicycle-sharing systems allow people to share bicycles with others, borrow and return them using multiple cycle ports, and register and pay for them with an IC card or smartphone. Because these systems are still new in Japan, few papers can be found on them, even in the National Institute of Informatics. The purpose of this article is to clarify the business purpose, issues, effects, features, numerical values, and direction of bicycle-sharing systems. Therefore, we selected 16 advanced cases nationwide and conducted a survey in 2019. As a result, it was clarified that the main issues facing bicycle-sharing systems are improving the ease of migration and supplementing public transportation, improving profitability, and so on.
\end{abstract}

Keywords: Bicycle-Sharing System, Case Study, Direction

\section{Introduction (Background and purpose of research, method)}

In Japan, the Bicycle Utilization Promotion Law was passed in 2017, and town development and bicyclesharing businesses have been progressing since. Bicyclesharing is a system that allows users to share bicycles and freely get on and off at multiple ports.

In addition, bicycle-sharing systems alleviate traffic congestion in cities, save energy, prevent air pollution, reduce travel costs, and improve public health. Therefore, they have recently become widespread in urban municipalities nationwide. However, previous research is not sufficient, and no paper has considered the management trends, issues, and directions of bicyclesharing systems by conducting a survey of advanced local governments all over Japan.

To fill this gap, 16 advanced cases nationwide were selected and a survey was conducted in 2019. The

(C) The 2021 International Conference on Artificial Life and Robotics (ICAROB2021), January 21 to 24, 2021 purpose of this article is to clarify the business purpose, issues, effects, features, numerical values (number of ports, number of bicycles, etc.), and direction of the 16 cases and to secure useful materials for the introduction of bicycle-sharing systems in the future. For the selection of the precedent cases in April 2019, local governments with a proven track record were selected from online searches, literature, and interviews with the Ministry of Land, Infrastructure, Transport and Tourism.

A survey of local governments was conducted from May to October 2019. In addition, we visited with the majority of the selected local governments to conduct interviews and collect materials.

\section{Research results}

(1) The most common purpose of the bicycle-sharing businesses is to improve the mobility of the town (10 cases). In particular, the effects of revitalizing the 
central city area and enhancing the convenience of transportation for tourists have increased.

Next, bicycle-sharing systems aim to help society break away from its dependence on automobiles (4 cases) and reduce the environmental burden (4 cases) by switching to using bicycles. The third most common purpose is to supplement public transportation ( 3 cases) and focus on bike-sharing as a means of promoting the use of public transportation.

Interregional exchange or the promotion of recreation (1 case) is also the goal of a wide-area bicycle-sharing system that spans multiple prefectures.

(2) In terms of actual effects or advantages, bicyclesharing systems contribute most to tourism (7 cases). In particular, they are highly effective as a means of transportation that could increase the number of users for sightseeing purposes and help tourists plan sightseeing excursions at their own pace.

Next, we have achieved about $50 \%$ of the purpose of improving the ease of migration ( 5 cases). In addition, the supplementation of public transportation (4 cases) has also been effective, including the development of regional transportation and the establishment of regional transportation networks. The introduction of electric bicycles ( 4 cases) has been well received by users, and people are able to travel smoothly. PR (6 cases) concerning these efforts has also been effective.

There were three PR projects that improved the recognition of this project throughout the region. According to survey participants, the development of guided bicycle tours, the suppression of the inflow of automobiles into the city ( 2 cases), and the conversion from automobiles to bicycle use (1 case) have been achieved.

(3) The most common problems/issues are the improvement of expenses such as balance of income and expenditures and costs ( 8 cases). Regarding this, survey participants expressed the opinion that a review of the fee structure should be considered in consideration of the profitability of the business.

The next most common issue is securing more users and creating PR for that purpose ( 5 cases). The third issue is the relocation of bicycles (4 cases), which is based at each port. Since it is possible to return a bicycle to a port different from the one from which you rented, the number of bicycles at the ports will be uneven. The high labor costs necessary for the relocation of bicycles is still an issue. In addition, there is a problem of selecting candidate locations for port installation (3 cases). It is necessary to take into consideration the assumption of possible harmful effects such as new construction, location conditions that are more effective in improving the utilization rate, and an increase in the number of illegally parked bicycles. The problem of manners when users use bicycles and the risk of accidents (3 cases) were also issues. Problems with maintenance of management systems and equipment (2 cases), simplification of membership registration (1 case), improvement of the environment for inbound tourists ( 1 case), and low use by citizens ( 1 case) were also mentioned.

(4) Relationship between population size, number of bicycles, and number of ports

See the correlation between the population size of each municipality, the number of bicycles installed, and the number of ports in the bike-share example.

It is expected that the bicycle-sharing system of a city with a large population will have a large number of bicycles and ports. Figures 1 and 2 are correlation diagrams of population size, the number of bicycles installed, and the number of ports; they were created from the data in Table 1. Regarding population size and the number of ports, the larger the population, the larger the number of ports and the correlation. On the other hand, regarding the relationship between population size and the number of bicycles, there are some data with large outliers, and there is little correlation in the overall value. The data with particularly large outliers is that of "Shimanami Rental Cycle (Imabari City / Onomichi City)." Unlike other local governments, Shimanami Rental Cycle emphasizes external effects such as widearea sightseeing tours. As a result of arranging bicycles for tourists, the proportion of the local population is higher than in other cases, i.e., the number of bicycles was large. However, Imabari and Onomichi on the Shimanami route; Takamatsu, a city that frequently uses bicycles; and Koto Ward, which is located in Megalopolis in the metropolitan area, are considered to be special, and there is a correlation in cities other than these. 
Table 1. Contents of advanced cases of bicycle-sharing systems in each local government in Japan

\begin{tabular}{|c|c|c|c|c|c|c|c|c|}
\hline Municipality & Okayama City & Miyazaki City & Koto-ku, Tokyo & Takamatsu City & Imabari City & Onomichi City & Fujieda City & Fukuoka City \\
\hline Name & Momochari & Miyako PiPPA & $\begin{array}{l}\text { Koto Ward } \\
\text { Seaside } \\
\text { Community } \\
\text { Cycle }\end{array}$ & $\begin{array}{l}\text { Takamatsu City } \\
\text { Bicycle Rental }\end{array}$ & \multirow{2}{*}{\multicolumn{2}{|c|}{ Shimanami Rental Cycle }} & $\begin{array}{l}\text { Fujieda Trip (bike } \\
\text { share in the city) }\end{array}$ & $\begin{array}{l}\text { Melchary (currently } \\
\text { in the demonstration } \\
\text { experiment stage) }\end{array}$ \\
\hline Start date & $7 / 27 / 2013$ & Jul-17 & Nov-12 & May-01 & Apr-99 & & Mar-18 & Mar-15 \\
\hline $\begin{array}{l}\text { Number of } \\
\text { bicycles }\end{array}$ & $\begin{array}{l}332 \text { units } \\
\text { (as of H27) }\end{array}$ & 200 units & $\begin{array}{l}1,207 \text { units } \\
\text { (as of R1.8.30) }\end{array}$ & $\begin{array}{l}1,250 \text { units } \\
\text { (as of R1) }\end{array}$ & 1,800 units & $\begin{array}{l}1,025 \\
\text { (Onomichi City } \\
\text { side as of } \\
\text { August 2019) } \\
\end{array}$ & $\begin{array}{l}45 \text { units (with } \\
\text { electric assist) }\end{array}$ & About 1,000 \\
\hline Number of ports & $\begin{array}{l}\text { 35 locations } \\
\text { (1 of which is } \\
\text { closed as of } \\
\text { R1.8) }\end{array}$ & 42 places & 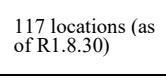 & 7 places & $\begin{array}{l}13 \text { locations } \\
\text { (9 locations in } \\
\text { Imabari City) }\end{array}$ & $\begin{array}{l}13 \text { locations (5 } \\
\text { locations on the } \\
\text { Onomichi side) }\end{array}$ & 16 places & $\begin{array}{l}\text { More than } 180 \\
\text { locations } \\
\text { (as of } \mathrm{H} 30 \text { ) }\end{array}$ \\
\hline $\begin{array}{l}\text { Registration } \\
\text { number }\end{array}$ & $\begin{array}{l}91,714 \text { people } \\
\text { (as of H30 } 130 \\
\text { degrees) }\end{array}$ & $\begin{array}{l}2,700 \text { (as of } \\
\mathrm{H} 31.6 .30 \text { ) }\end{array}$ & $\begin{array}{l}\text { 128,804 people } \\
\text { (as of December } \\
31, \mathrm{H} 30)\end{array}$ & --- & --- & -- & --- & -- \\
\hline $\begin{array}{l}\text { User registration } \\
\text { IA: port, B: } \\
\text { smartphone app, } \\
\text { C: web, w: D: } \\
\text { window] } \\
\end{array}$ & A & B & $\mathrm{C}$ & D & \multicolumn{2}{|c|}{ D } & B & B \\
\hline $\begin{array}{l}\text { Payment method } \\
\text { [A: cash, B: credit } \\
\text { card, C: mobile } \\
\text { phone payment, } \\
\text { D: IC card, E: } \\
\text { electronic money, } \\
\text { F: other] }\end{array}$ & $\mathrm{A}, \mathrm{B}, \mathrm{D}, \mathrm{F}$ & B, C, D, E, F & $\mathrm{A}, \mathrm{B}, \mathrm{C}, \mathrm{D}$ & A, D & \multicolumn{2}{|c|}{ A } & $\mathrm{B}, \mathrm{C}$ & $\mathrm{B}, \mathrm{F}$ \\
\hline$\underset{\text { Operational }}{\text { trends }}$ & 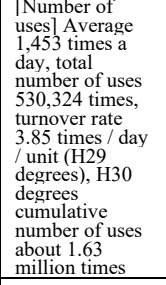 & $\begin{array}{l}\text { The breakdown of } \\
\text { the occupancy } \\
\text { rate of the port } \\
\text { utilization rate is } \\
62.1 \% \text { for public } \\
\text { land (17 pulic } \\
\text { locations), 37.7\% } \\
\text { for private land } \\
\text { (25 locations), } \\
\text { and 0.2\% } \\
\text { unknown. }\end{array}$ & $\begin{array}{l}\text { Bicycles may be } \\
\text { parked } \\
\text { excessively, and } \\
\text { collection and } \\
\text { reloction work } \\
\text { to level the } \\
\text { number of } \\
\text { bicycles is } \\
\text { increasing. }\end{array}$ & $\begin{array}{l}\text { Operated by } \\
\text { bicycles with } \\
\text { abandoned } \\
\text { bicycles } \\
\text { Annual usage: } \\
\text { Approximately } \\
\text { 310,000 }\end{array}$ & $\begin{array}{l}\text { Approximately } \\
155,000 \text { annual } \\
\text { users }\end{array}$ & $\begin{array}{l}\text { [Number of } \\
\text { loans (fiscal } \\
\text { year)] }\end{array}$ & $\begin{array}{l}\text { Reiwa first year } \\
\text { budget amount: } \\
10,000,000 \text { yen } \\
* 2017 \text { budget } \\
\text { amount: } \\
2,000,000 \text { yen, } \\
2018 \text { budget } \\
\text { amount: } 4,500,000 \\
\text { yen }\end{array}$ & $\begin{array}{l}\text { Mercari dismantled } \\
\text { its consolidated } \\
\text { subsidiary Sozo in } \\
\text { June } 2019 \text { and } \\
\text { started a new } \\
\text { company "neuet" in } \\
\text { August. Operated in } \\
\text { the form of a joint } \\
\text { system between } \\
\text { "Co., Ltd." and } \\
\text { "Clara Online Co., } \\
\text { Ltd." }\end{array}$ \\
\hline $\begin{array}{l}\text { Port with many } \\
\text { users }\end{array}$ & --- & $\begin{array}{l}\text { High utiliization } \\
\text { rate of ports on } \\
\text { public land under } \\
\text { demonstration } \\
\text { experiment }\end{array}$ & $\begin{array}{l}\text { Mostly used for } \\
\text { commuting on } \\
\text { weekday } \\
\text { mornings and } \\
\text { evenings. In } \\
\text { particular, there } \\
\text { are many uses of } \\
\text { ports near tower } \\
\text { apartments and } \\
\text { stations. }\end{array}$ & $\begin{array}{l}\text { JR Takamatsu } \\
\text { station square } \\
\text { underground } \\
\text { port and } \\
\text { Kotoden } \\
\text { Kawaramachi } \\
\text { station } \\
\text { underground } \\
\text { port } \\
\end{array}$ & -- & -- & -- & --- \\
\hline Pros & $\begin{array}{l}\text { - Change of } \\
\text { traffic behavior, } \\
\text { revitalization of } \\
\text { town } \\
\text {-Reduction of } \\
\text { environmental } \\
\text { load }\end{array}$ & $\begin{array}{l}\text { Environmentally } \\
\text { friendly and eco- } \\
\text { friendly, } \\
\text { contributing to } \\
\text { health promotion }\end{array}$ & $\begin{array}{l}\text { Reduction of } \\
\text { CO } 2 \text { by reducing } \\
\text { the movement of } \\
\text { automobiles, } \\
\text { improvement of } \\
\text { attractivenenss of } \\
\text { the introduction } \\
\text { area, } \\
\text { improvement of } \\
\text { convenience of } \\
\text { movement, of } \\
\text { creation of } \\
\text { liveliness by } \\
\text { improvement of } \\
\text { mobility in the } \\
\text { area, etc. }\end{array}$ & $\begin{array}{l}\text { Control the total } \\
\text { amount of } \\
\text { bicycles through } \\
\text { mutual use and } \\
\text { effectively y } \\
\text { utilizi eillegally } \\
\text { parked bicycles }\end{array}$ & $\begin{array}{l}\text { Promotion of } \\
\text { sta-type } \\
\text { tourism, } \\
\text { promotion of } \\
\text { health, } \\
\text { promotion of } \\
\text { purpose of life } \\
\text { and friendshiph, } \\
\text { realization of a } \\
\text { society with } \\
\text { reduced } \\
\text { environmental } \\
\text { load, promotion } \\
\text { of inbound } \\
\text { tourism due to } \\
\text { international } \\
\text { popularity }\end{array}$ & $\begin{array}{l}\text { You can enjoy } \\
\text { the beauty of the } \\
\text { islands of } \\
\text { Setouchi, } \\
\text { interact with the } \\
\text { locals, and enioy } \\
\text { gourmet food at } \\
\text { your own pace. }\end{array}$ & $\begin{array}{l}\text { 11 Cheaper than a } \\
\text { bus and convenient } \\
\text { with no waiting } \\
\text { time. You can } \\
\text { easily climb a } \\
\text { slope with an } \\
\text { electric bicycle. (2) } \\
\text { There is a station at } \\
\text { Furieda } \\
\text { station. Available } \\
24 \text { hours a day. (3) } \\
\text { There is no } \\
\text { problem even if } \\
\text { you use it if } \\
\text { frequently. It's } \\
\text { cheaeer than } \\
\text { parkng in the } \\
\text { parking lot. }\end{array}$ & $\begin{array}{l}\text { - Use unused space } \\
\text { as a port (individual } \\
\text { application required) } \\
\text { - Can travel short } \\
\text { distances faster than } \\
\text { using public } \\
\text { transportation }\end{array}$ \\
\hline Problems/issues & $\begin{array}{l}\cdot \text { Simplification } \\
\text { of membership } \\
\text { registration } \\
\text { method } \\
\dot{\text { Dissemination }} \\
\text { of first-time } \\
\text { users } \\
\text {-PR for } \\
\text { increasing users } \\
\text { for sightseeing } \\
\text { purposes } \\
\text { - Elimination of } \\
\text { bicycle bias at } \\
\text { each port }\end{array}$ & $\begin{array}{l}\text { There is concern } \\
\text { that the risk of } \\
\text { accidents due to } \\
\text { crossing with } \\
\text { automobolies and } \\
\text { pedestrians is } \\
\text { increasing due to } \\
\text { the lack of } \\
\text { following traffic } \\
\text { rules such as } \\
\text { driving on the left } \\
\text { side of the road. }\end{array}$ & $\begin{array}{l}\text { Improved } \\
\text { income and } \\
\text { expenditure by } \\
\text { streamlining the } \\
\text { collection and } \\
\text { relocation of } \\
\text { expensive } \\
\text { bicycles } \\
\text { - Optimization of } \\
\text { the number of } \\
\text { bicycles at the } \\
\text { cycle port }\end{array}$ & $\begin{array}{l}\cdot \text { Improvement } \\
\text { of balance of } \\
\text { income and } \\
\text { expenditure } \\
\text { - Update of } \\
\text { management } \\
\text { system due to } \\
\text { deterioration } \\
\text { over time }\end{array}$ & $\begin{array}{l}\text { Inbound } \\
\text { environment } \\
\text { maintenance } \\
\text { (Wi-Fi } \\
\text { (environment } \\
\text { communication } \\
\text { means, cashless } \\
\text { payment) }\end{array}$ & $\begin{array}{l}\text { As the number } \\
\text { of cyclists } \\
\text { increased, we } \\
\text { began to hear } \\
\text { complaints } \\
\text { about driving } \\
\text { manners }\end{array}$ & $\begin{array}{l}\text {-Implementation } \\
\text { of effective PR to } \\
\text { increase the } \\
\text { number of users } \\
\text { - Selection of } \\
\text { station installation } \\
\text { locations that are } \\
\text { expected to be } \\
\text { used } \\
\text {-Reduction of } \\
\text { running costs }\end{array}$ & $\begin{array}{l}\text { - There is a } \\
\text { possibility that the } \\
\text { correct position of } \\
\text { the bicccle will not } \\
\text { be displayed on the } \\
\text { app due to GPS } \\
\text { accuracy } \\
\text { - There are users with } \\
\text { bad manners such as } \\
\text { personalization as } \\
\text { - Because there is no } \\
\text { reservation system, } \\
\text { other people will use } \\
\text { the bicccle first } \\
\text { (possibility of not } \\
\text { being alle to ride } \\
\text { when you want to) } \\
\end{array}$ \\
\hline Direction & 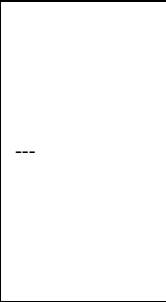 & --- & $\begin{array}{l}\text { Examining and } \\
\text { implementing } \\
\text { problems and } \\
\text { solutions to } \\
\text { problems in } \\
\text { demonstration } \\
\text { experiments, and } \\
\text { shifting to full- } \\
\text { scale } \\
\text { implementation }\end{array}$ & 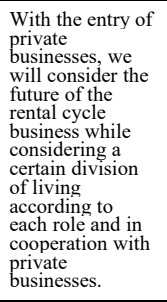 & $\begin{array}{l}\text { Expanding the } \\
\text { base of cyclists } \\
\text { by attracting } \\
\text { non-cyclists } \\
\text { such as the } \\
\text { elderly and } \\
\text { women }\end{array}$ & $\begin{array}{l}\text { We will } \\
\text { contine to } \\
\text { disseminate } \\
\text { information on } \\
\text { the appeal of } \\
\text { Shimanami } \\
\text { Kaido Cycling } \\
\text { both } \\
\text { domestically } \\
\text { and } \\
\text { internationally, } \\
\text { and strive to to } \\
\text { improve the } \\
\text { driving } \\
\text { environment and } \\
\text { manners. }\end{array}$ & $\begin{array}{l}\text { While taking in the } \\
\text { opinions of users } \\
\text { through effective } \\
\text { PR and surveys, } \\
\text { we will improve } \\
\text { the utilization rate } \\
\text { and ease of rate } \\
\text { migration. Since it } \\
\text { is an initiative that } \\
\text { utilizes IoT, we } \\
\text { will consider how } \\
\text { to utilize usage } \\
\text { data. }\end{array}$ & $\begin{array}{l}\text { Business succession } \\
\text { was passed to "neuet } \\
\text { Co., Ltt." and the } \\
\text { Mercari business as a } \\
\text { new system started in } \\
\text { collaboration with } \\
\text { "Clara Online". } \\
\text { "The purpose of the } \\
\text { new system is to } \\
\text { focus on Mercari and } \\
\text { Mercari. Results of } \\
\text { business selection } \\
\text { and further business } \\
\text { expansion" }\end{array}$ \\
\hline
\end{tabular}

(C) The 2021 International Conference on Artificial Life and Robotics (ICAROB2021), January 21 to 24, 2021 
Table 1. (Continued)

\begin{tabular}{|c|c|c|c|c|c|c|c|c|}
\hline Municipality & $\begin{array}{c}\text { Kagoshima } \\
\text { City }\end{array}$ & Kitakyushu & Oita City & Hiroshima City & Fukui City & Toyama City & Himeji City & Kanazawa \\
\hline Name & $\begin{array}{l}\text { Kagoshima City } \\
\text { Community } \\
\text { Cycle "Kagorin" }\end{array}$ & $\begin{array}{c}\text { Kitakyushu City } \\
\text { Bike }\end{array}$ & $\begin{array}{l}\text { Oita Cycle } \\
\text { Share }\end{array}$ & $\begin{array}{c}\text { Hiroshima City } \\
\text { Peasukuru }\end{array}$ & Fukui City & $\begin{array}{c}\text { Toyama City } \\
\text { Avile }\end{array}$ & $\begin{array}{c}\text { Himeji City } \\
\text { Himeji }\end{array}$ & $\begin{array}{c}\text { Kanazawa City } \\
\text { Machinori }\end{array}$ \\
\hline $\begin{array}{c}\text { Start date } \\
\text { Number of bicycles }\end{array}$ & $\begin{array}{c}\text { Mar-15 } \\
192 \text { units }\end{array}$ & $\frac{\text { Mar-10 }}{246 \text { units }}$ & $\begin{array}{c}\text { Oct-18 } \\
300 \text { units }\end{array}$ & $\begin{array}{c}\text { Feb-15 } \\
\text { About 500 }\end{array}$ & $\begin{array}{c}2013 \\
44 \text { units }\end{array}$ & $\begin{array}{c}\text { Mar-10 } \\
255 \text { units }\end{array}$ & $\begin{array}{c}\text { Jul-16 } \\
150 \text { units }\end{array}$ & Mar-12 \\
\hline Number of ports & $\begin{array}{l}25 \text { locations (as } \\
\text { of } \mathrm{R} 1 / 7 \text { ) }\end{array}$ & 21 places & 35 places & 62 locations & $\begin{array}{l}44 \text { units } \\
\text { portsber of } 16 \\
\text { locations (as of } \\
\text { R1/7) }\end{array}$ & $\begin{array}{l}\text { TNumber of } \\
\text { ports } 123 \\
\text { locations (as of } \\
\text { R1/9) }\end{array}$ & $\begin{array}{l}150 \text { units } \\
\text { pormber of } \\
\text { locations (as of } \\
\text { R1/7) }\end{array}$ & $\begin{array}{l}153 \text { units } \\
{[\text { Number of }} \\
\text { ports] } 21 \\
\text { locations }\end{array}$ \\
\hline Registration number & --- & $\begin{array}{l}535 \text { general } \\
\text { members } \\
\text { Shear type } \\
\text { (corporate) } 45 \\
\text { (as of R1/5) } \\
\end{array}$ & $\begin{array}{l}\text { Approximately } \\
1,000 \text { people (as } \\
\text { of } \mathrm{R} 1 / 7 \text { ) }\end{array}$ & --- & --- & --- & $\begin{array}{l}180 \text { units (as of } \\
\mathrm{R} 1 / 7 \text { ) }\end{array}$ & $\begin{array}{l}\text { 296,616 people } \\
\text { (H24/3/21- } \\
\mathrm{H} 31 / 3 / 31)\end{array}$ \\
\hline $\begin{array}{l}\text { User registration A A: port, } \\
\text { B: smartphone app, C: } \\
\text { web, D: window] }\end{array}$ & A, D & C, D & $\mathrm{B}, \mathrm{C}$ & C, D & D & D & $\mathrm{A}, \mathrm{C}$ & A, D \\
\hline $\begin{array}{l}\text { Payment method }[\mathrm{A}: \\
\text { cash, B: credit card, C: } \\
\text { mobile phone payment, } \\
\text { D: IC card, E: electronic } \\
\text { money, F: other] }\end{array}$ & $\mathrm{A}, \mathrm{B}, \mathrm{E}$ & $\mathrm{A}, \mathrm{B}, \mathrm{C}$ & $\mathrm{B}, \mathrm{F}$ & A, B, C, D & A & $\mathrm{A}, \mathrm{B}, \mathrm{F}$ & A, B & $\mathrm{A}, \mathrm{B}$ \\
\hline Operational trends & $\begin{array}{l}\text { The number of } \\
\text { uses increases } \\
\text { year by year (the } \\
\text { total number of } \\
\text { uses until the } \\
\text { end of July of } \\
\text { the first year of } \\
\text { Reiwa is about } \\
670,000)\end{array}$ & $\begin{array}{l}\text { Number of } \\
\text { users: } 147 \text { units / } \\
\text { day (2018) }\end{array}$ & $\begin{array}{l}\text { The monthly } \\
\text { membership free } \\
\text { campaign was } \\
\text { held from } \\
\text { February } 12, \\
2019 \text { to June } 30, \\
2019 \text {, and the } \\
\text { usage increased } \\
\text { significantly. }\end{array}$ & $\begin{array}{l}\text { Consignment } \\
\text { contract amount } \\
2014 \ldots \ldots \\
20,000,000 \text { yen } \\
2015 \ldots \ldots \\
18,000,000 \text { yen } \\
2016 \ldots \ldots \\
14,000,000 \text { yen } \\
2017 \text { yen } 2018 \ldots \\
\ldots, 300,000 \text { yen }\end{array}$ & $\begin{array}{l}\text { The number of } \\
\text { uses is } \\
\text { increasing year } \\
\text { by year, and the } \\
\text { demand is } \\
\text { increasing, } \\
\text { especially } \\
\text { in. We are able } \\
\text { to operate the } \\
\text { business on a } \\
\text { low budget } \\
\text { while } \\
\text { coordinating } \\
\text { with the private } \\
\text { sector. }\end{array}$ & --- & $\begin{array}{l}\text { The share cycle } \\
\text { has become } \\
\text { established as a } \\
\text { secondary means } \\
\text { of transportation, } \\
\text { and the number } \\
\text { of users and the } \\
\text { number of times } \\
\text { of use are } \\
\text { increasing year } \\
\text { by year. }\end{array}$ & $\begin{array}{l}\text { Number of uses } \\
178,619 \text { times, } \\
\text { number of users } \\
63,284 \text { (2018) }\end{array}$ \\
\hline Port with many users & --- & --- & --- & --- & $\begin{array}{l}\text { Port around } \\
\text { Fukui Station }\end{array}$ & $\begin{array}{l}\text { Three stations at } \\
\text { the south exit of } \\
\text { Toyama Station, } \\
\text { Nishicho Station } \\
\text { (located in front } \\
\text { of Toyama City } \\
\text { Hall), and in the } \\
\text { city center }\end{array}$ & $\begin{array}{l}\text { Ports around } \\
\text { Himeji Station, } \\
\text { often used for } \\
\text { commuting and } \\
\text { sightseeing }\end{array}$ & $\begin{array}{l}\text { Most often used } \\
\text { at Kanazawa } \\
\text { Station, the } \\
\text { starting point, } \\
\text { and ports around } \\
\text { major tourist } \\
\text { destinations }\end{array}$ \\
\hline Pros & $\begin{array}{l}\text { Reducing } \\
\text { environmental } \\
\text { impact, } \\
\text { improving } \\
\text { mobility and } \\
\text { convenience, } \\
\text { responding to a } \\
\text { wide range of } \\
\text { tourism needs } \\
\text { (attractiveness of } \\
\text { town tours } \\
\text { unique to } \\
\text { bicycles) }\end{array}$ & $\begin{array}{l}\text { By shifting to } \\
\text { the use of } \\
\text { bicycles, it is } \\
\text { possible to } \\
\text { reduce the } \\
\text { environmental } \\
\text { load by means } \\
\text { such as } \\
\text { reduction of } \\
\text { carbon dioxide } \\
\text { emissions, } \\
\text { electronic } \\
\text { assistance, and } \\
\text { "drop offs" } \\
\text { between } \\
\text { stations. }\end{array}$ & $\begin{array}{l}\cdot \text { Y You can drop } \\
\text { off } \\
\text { - You don't have } \\
\text { to wait like for a } \\
\text { bus } \\
\text { - You can use it } \\
24 \text { hours a day } \\
\cdot \text { Contribute to } \\
\text { the } \\
\text { establishment of } \\
\text { a regional } \\
\text { transportation } \\
\text { network by } \\
\text { combining with } \\
\text { the public } \\
\text { transportation } \\
\text { network }\end{array}$ & $\begin{array}{l}\text { Because it is a } \\
\text { city of deltas, } \\
\text { you can } \\
\text { smoothly tour } \\
\text { the city with } \\
\text { many undulating } \\
\text { bridges by } \\
\text { electric bicycle }\end{array}$ & $\begin{array}{l}\text { All of them are } \\
\text { equipped with } \\
\text { electric power } \\
\text { assist and } \\
\text { rentals are } \\
\text { accepted face- } \\
\text { to-face, so we } \\
\text { can provide } \\
\text { tourists } \\
\text { information as } \\
\text { well as rental } \\
\text { services. }\end{array}$ & $\begin{array}{l}\text { Cyclocity Co., } \\
\text { Ltd., the } \\
\text { operator, is } \\
\text { operating } \\
\text { smoothly and } \\
\text { safely by making } \\
\text { the best use of } \\
\text { the know-how } \\
\text { cultivated so far. }\end{array}$ & $\begin{array}{l}\text { It can be used } \\
\text { with cash, and it } \\
\text { can be used } \\
\text { immediately } \\
\text { without the need } \\
\text { for pre- } \\
\text { registration or } \\
\text { other operations. }\end{array}$ & $\begin{array}{l}\text {-If you have a } \\
\text { credit card, you } \\
\text { can easily } \\
\text { register on the } \\
\text { spot } \\
\text { - There are many } \\
\text { narrow streets in } \\
\text { the city of } \\
\text { Kanazawa, and } \\
\text { the main tourist } \\
\text { spots are } \\
\text { concentrated in } \\
\text { a narrow area, } \\
\text { so it is suitable } \\
\text { as a means of } \\
\text { transportation } \\
\text { for tourists }\end{array}$ \\
\hline Problems/issues & $\begin{array}{l}\text { Continue to } \\
\text { strive for public } \\
\text { relations and } \\
\text { maintenance of } \\
\text { equipment, etc. }\end{array}$ & $\begin{array}{l}\cdot \text { Ensuring } \\
\text { business } \\
\text { profitability } \\
\cdot \text { A large ratio of } \\
\text { labor costs to } \\
\text { correct the bias } \\
\text { of bicycles } \\
\text { between stations }\end{array}$ & $\begin{array}{l}\text {-It costs a lot of } \\
\text { "relocation" to } \\
\text { correct the bias } \\
\text { of bicycle } \\
\text { placement } \\
\text {-It takes a } \\
\text { certain period of } \\
\text { time to increase } \\
\text { the number of } \\
\text { users }\end{array}$ & $\begin{array}{l}\text { As a candidate } \\
\text { for port } \\
\text { installation, it is } \\
\text { a highly } \\
\text { convenient } \\
\text { place, but there } \\
\text { are times when } \\
\text { it is necessary to } \\
\text { abandon the } \\
\text { installation due } \\
\text { to concerns } \\
\text { about problems } \\
\text { caused by } \\
\text { installing the } \\
\text { port, such as the } \\
\text { number of } \\
\text { illegally parked } \\
\text { bicycles } \\
\text { increasing }\end{array}$ & $\begin{array}{l}\text { Business } \\
\text { management } \\
\text { that is conscious } \\
\text { of the difficulty } \\
\text { of establishing a } \\
\text { new lending } \\
\text { port and } \\
\text { profitability }\end{array}$ & $\begin{array}{l}\text { Stable securing } \\
\text { of financial } \\
\text { resources such } \\
\text { as operation and } \\
\text { maintenance } \\
\text { costs for } \\
\text { properly } \\
\text { conducting the } \\
\text { bicycle-sharing } \\
\text { business }\end{array}$ & $\begin{array}{l}\cdot \text { Efforts to } \\
\text { increase the } \\
\text { number of users } \\
\cdot \text { Naming rights } \\
\text { and other } \\
\text { advertising } \\
\text { revenues need to } \\
\text { be expanded, fee } \\
\text { structure } \\
\text { reviewed and } \\
\text { costs reduced }\end{array}$ & $\begin{array}{l}\text { - Low citizen } \\
\text { use (about } 90 \% \\
\text { of the total is for } \\
\text { tourism) } \\
\text { - Increase in } \\
\text { repair costs over } \\
\text { time }\end{array}$ \\
\hline Direction & $\begin{array}{l}\text { By } \\
\text { communicating } \\
\text { the significance } \\
\text { of riding a } \\
\text { bicycle in an } \\
\text { easy-to- } \\
\text { understand and } \\
\text { polite manner, } \\
\text { we will further } \\
\text { increase interest } \\
\text { and } \\
\text { understanding of } \\
\text { bicycles }\end{array}$ & $\begin{array}{l}\text { Aiming to } \\
\text { continue } \\
\text { business while } \\
\text { selecting } \\
\text { stations that } \\
\text { better meet } \\
\text { needs }\end{array}$ & $\begin{array}{l}\text { We would like } \\
\text { to set up a } \\
\text { service area so } \\
\text { that the } \\
\text { relocation work } \\
\text { will not be } \\
\text { excessive, } \\
\text { balance the } \\
\text { income and } \\
\text { expenditures, } \\
\text { and verify that it } \\
\text { will be } \\
\text { established as a } \\
\text { sustainable new } \\
\text { transportation } \\
\text { system. }\end{array}$ & $\begin{array}{l}\text { High density of } \\
\text { cycle ports so } \\
\text { that domestic } \\
\text { and foreign } \\
\text { tourists and } \\
\text { other visitors } \\
\text { can comfortably } \\
\text { visit tourist } \\
\text { facilities in the } \\
\text { city area and } \\
\text { citizens can } \\
\text { conveniently use } \\
\text { the ports as a } \\
\text { means of daily } \\
\text { use that } \\
\text { complements } \\
\text { public } \\
\text { transportation. } \\
\text { Promote tourism } \\
\text { and regional } \\
\text { revitalization } \\
\text { using bicycles }\end{array}$ & $\begin{array}{l}\text { We increased } \\
\text { the operating } \\
\text { rate of bicycles } \\
\text { by driving up } \\
\text { demand, and } \\
\text { based on that } \\
\text { situation, we } \\
\text { considered } \\
\text { establishing new } \\
\text { rental ports and } \\
\text { increasing the } \\
\text { number of } \\
\text { turntables. }\end{array}$ & $\begin{array}{l}\text { The expansion } \\
\text { of stations and } \\
\text { services has just } \\
\text { been } \\
\text { implemented by } \\
\text { the operator in } \\
\text { consideration of } \\
\text { profitability, } \\
\text { etc., and there } \\
\text { are no plans to } \\
\text { expand at this } \\
\text { time. }\end{array}$ & $\begin{array}{l}\text { While } \\
\text { considering the } \\
\text { number of } \\
\text { bicycles and the } \\
\text { arrangement of } \\
\text { stations that } \\
\text { meet the needs, } \\
\text { we will proceed } \\
\text { with the } \\
\text { introduction of } \\
\text { an "in-vehicle } \\
\text { share cycle" that } \\
\text { can reduce } \\
\text { operating costs } \\
\text { compared to the } \\
\text { current system as } \\
\text { a "next } \\
\text { generation } \\
\text { Hime-chari." }\end{array}$ & $\begin{array}{l}\text { A new system } \\
\text { started from } \\
\text { March } 2^{\text {nd }} \text { year } \\
\text { of Reiwa. Basic } \\
\text { direction: (1) } \\
\text { Encourage } \\
\text { citizens to use } \\
\text { (currently, users } \\
\text { are mainly } \\
\text { tourists); (2) } \\
\text { Respond to new } \\
\text { tourism demand } \\
\text { based on the } \\
\text { central city area; } \\
\text { (3) Maintain } \\
\text { public-private } \\
\text { management } \\
\text { and other } \\
\text { electric assists in } \\
\text { order to comply } \\
\text { with the policy } \\
\text { of town } \\
\text { development } \\
\text { Equipped with } \\
\text { functions and } \\
\text { GPS functions }\end{array}$ \\
\hline
\end{tabular}




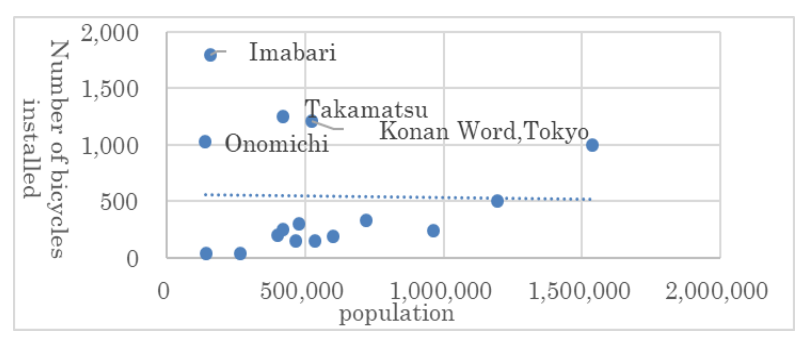

Figure1. Relationship between population size and number of bicycles

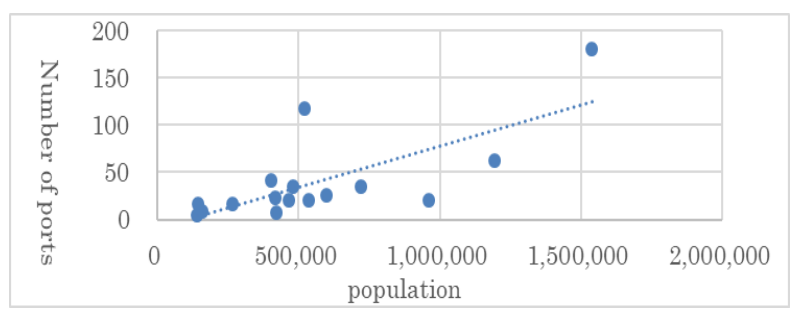

Figure2. Correlation diagram between population size and number of port

\section{Conclusion}

According to a nationwide survey, the number of cycle ports and the number of users are correlated in the bicycle-sharing businesses located in urban areas, and the cycle ports located at railway stations representing the cities have the highest utilization rates. Cycle ports with heavy traffic at transportation hubs have many users, complementing public transportation; shortening travel times for sightseeing, commuting to school, business, etc.; and increasing mobility. However, it is difficult to make a profit in the bicycle-sharing business, so most of these businesses are subsidized by the local government. Large-scale bicycle-sharing businesses with a relatively large number of cycle ports and bicycles have a higher turnover rate and are more likely to improve profitability than small bicycle-sharing businesses.

Therefore, for the sustainable development of bicyclesharing businesses in the future, it is important to secure the number of bike-share ports and the number of bicycles in a convenient position commensurate with the size of the population and to devise ways to improve profitability, for example, in Toyama City. As you can see, new ideas and implementations are needed, such as attaching electronic public notices to cycle ports to earn sponsorship income.
3. https://www.city.toyama.toyama.jp/kankyobu/kankyoseis akuka/ondankataisakukikaku/jitenshakyodoriyo.html

4. https://www.machi-nori.jp/

5. https://docomo-cycle.jp/koto/whatiscs/

6. https://www.keifuku-hotels.com/news/?p=65

7. https://www.momochari.jp/howto/index.html

8. http://www.city.hiroshima.lg.jp/www/contents/15815526 07625/index.html

9. http://www.city.kagoshima.lg.jp/faqkankyomachizukuri/kanseisaku/q9.html

10. https://hachimansama.jp/blog/9305\#

11. https://www.itmedia.co.jp/news/articles/1802/13/news11 5.html

12. https://www.kobe-np.co.jp/news/odekakeplus/news/detail.shtml?news/odekakeplus/news/pickup/201809/11648577

13. https://www.city.miyazaki.miyazaki.jp/city/policy/urban planning/164580.html

14. https://www.city.fujieda.shizuoka.jp/trip/oshirase/152118 4175837.html

15. https://rembrandt-group.com/oita/7842.html

\section{References}

1. https://shimanami-cycle.or.jp/rental/course

2. http://takamatsu-

parking.com/for_use_onetime_rider_2017/ 